\title{
Pengembangan Perangkat Pembelajaran Matematika Melalui Teori Pembelajaran Sibernetik Berbantuan Software Derive
}

\author{
S. Salim ${ }^{1 *}$, Era Maryanti ${ }^{1}$ \\ ${ }^{1}$ Jurusan Pendidikan Matematika, Universitas Halu Oleo. Kampus Bumi Tridharma Andounohu Kota \\ Kendari, 93231, Indonesia \\ * Corresponding Author. Email:salim@uho.ac.id \\ Received: 3 October 2017; Revised: 16 Desember 2017; Accepted: 28 December 2017
}

\begin{abstract}
Abstrak
Tujuan penelitian ini diantaranya: (1) menemukan karakteristik perangkat pembelajaran yang dikembangkan, (2) mendeskripsikan kevalidan perangkat pembelajaran, (3) menganalisis keefektifan pembelajaran menggunakan perangkat pembelajaran yang dikembangkan dan (4) menganalisis peningkatan kemampuan berpikir kritis siswa melalui pengunaan perangkat pembelajaran yang dikembangkan. Metode dalam penelitian ini menggunakan pendekatan Research And Development menggunakan model Plomp. Hasil penelitian ini diantaranya: (1) karakteristik perangkat pembelajaran yaitu mengandung komponen kemampuan berpikir kritis dan memanfaatkan TIK, (2) perangkat pembelajaran berkategori sangat valid, (3) efektif diterapkan dalam kegiatan pembelajaran matematika, (4) perangkat pembelajaran melalui teori pembelajaran sibernetik berbantuan software derive dapat meningkatkan kemampuan berpikir kritis matematis siswa
\end{abstract}

Kata kunci: pembelajaran sibernetik, derive, berpikir kritis

\section{Development of Mathematical Devices Learning Through the Learning Sibernetic Theory to Assisted Derive Software}

\begin{abstract}
The purpose of this research including: (1) find characteristic device learning developed, (2) described validity device learning, (3) analyze effectiveness of learning using learning devices developed and (4) analyzing the improved critical thinking ability of students through the use of a device of learning developed. The method in this research use approach to Research And Development using model Plomp .This research result of them: (1) learning device characteristics i.e. contain components of critical thinking ability and make use of ICT, (2) the very valid category of learning devices, (3) effectively applied in learning activities Mathematics, (4) the learning devices through the learning sibernetic theory to assisted derive software can improve the ability of students mathematical thinking critically
\end{abstract}

Keyword: learning sibernetic, derive, critical thinking

How to Cite: Salim, S., \& Maryanti, E. (2017). Pengembangan perangkat pembelajaran matematika melalui teori pembelajaran sibernetik berbantuan software derive. Jurnal Riset Pendidikan Matematika, 4(2), 229-238. doi:http://dx.doi.org/10.21831/jrpm.v4i2.16068

Permalink/DOI: http://dx.doi.org/10.21831/jrpm.v4i2.16068

\section{PENDAHULUAN}

Masalah rendahnya mutu hasil pendidikan merupakan masalah yang cukup kompleks karena penyebabnya dapat terdiri dari banyak faktor. Untuk menghadapi masalah rendahnya mutu hasil pendidikan itu perlu dicari berbagai kemungkinan penyebabnya yang berkaitan dengan berbagai faktor yang mempengaruhi keberhasilan belajar siswa dalam suatu bidang studi tertentu misalnya mata pelajaran matematika. Dalam pembelajaran matematika di Indonesia, kemampuan siswa dalam penguasaan matematika cukup rendah. Hal ini ditunjukkan dari data dunia Internasional bahwa pencapaian prestasi Indonesia dalam TIMSS (Trends in International Mathematics and Science Study) 


\title{
Jurnal Riset Pendidikan Matematika, 4 (2), 2017 - 230
}

\author{
S. Salim, Era Maryanti
}

tahun 2011 untuk bidang Matematika, Indonesia berada di urutan ke-38 dengan rata-rata skor 386 dari 42 negara dengan tes dilakukan pada siswa kelas 8 (IEA, 2011, p.4).

Proses pembelajaran matematika di sekolah juga menghadapi sejumlah masalah. Guru harus memilih dan menentukan materi, strategi, dan media pembelajaran yang tepat dalam rangka membantu siswa mencapai kompetensi tertentu. Hal ini karena kurangnya minat belajar matematika, kurangnya rasa keingintahuan dan kurangnya siswa berpikir kritis dalam belajar matematika, sehingga mengakibatkan siswa pasif dalam belajar matematika. Kurangnya rasa ingin tahu dan kekritisan yang terdapat dalam diri siswa, dan kecenderungan siswa belajar hanya dengan menghafal rumus saja tanpa mengaplikasikannya dalam kehidupan nyata. Hal itu belum dapat mendorong minat siswa dalam belajar matematika, sehingga hasil yang dicapai siswa selama proses pembelajaran belum optimal.

Murwani (2006, p.62) berpendapat seseorang yang berpikir kritis dapat mengajukan pertanyaan dengan tepat, memperoleh informasi yang relevan, efektif, dan kreatif dalam memilih informasi, alasan logis dari informasi, sampai pada kesimpulan yang dapat dipercaya dan meyakinkan tentang dunia yang memungkinkan untuk hidup dan beraktivitas dengan sukses di dalamnya. Berpikir kritis menurut Ennis dalam Anonim (2013b) memberikan sebuah definisi sebagai berikut, "Critical thinking is reasonable, reflective thinking that is focused on deciding what to believe and do" yang artinya berpikir kritis adalah berpikir secara beralasan dan reflektif dengan menekankan pembuatan keputusan tentang apa yang harus dipercayai atau dilakukan.

Pemikiran kritis menurut Browne dan Keeley dalam Jacobsen, Eggen, \& Kauchak (2009, pp.186-187), merujuk pada karakteristikkarakteristik siswa sebagai berikut; (1) kesadaran akan sederet pertanyaan-pertanyaan kritis yang saling berhubungan, (2) kemampuan bertanya dan menjawab pertanyaan-pertanyaan kritis pada saat yang tepat dan (3) keinginan untuk secara aktif mengajukan pertanyaanpertanyaan kritis

Fakta yang terjadi pada proses pembelajaran di kelas XI IPA SMA Negeri 1 Pasarwajo yaitu pembelajaran yang mengarah pada kemampuan berpikir kritis belum pernah diterapkan dalam kegiatan pembelajaran, pemberian konsep materi oleh guru matematika kepada siswa dilakukan secara ringkas diiringi dengan penyelesaian contoh soal yang sederhana, siswa mengalami kesulitan ketika menyelesaikan soal dalam bentuk yang bukan sederhana, indikator penilaian pembelajaran masih mengarah pada keterampilan berhitung saja, dan penggunaan teknologi dalam pembelajaran oleh guru matematika masih minim. Jika fenomena ini dibiarkan terus-menerus maka berdampak pada hasil pencapaian belajar siswa. Olehnya itu, perlu strategi pembelajaran yang melatih siswa untuk berpikir kritis dan penggunaan teknologi dalam pembelajaran untuk kepastian hasil pengerjaan soal dan visualisasi konsep matematika yang bersifat abstrak.

Kemampuan berpikir kritis dapat ditingkatkan dengan mengkombinasikan beberapa strategi pembelajaran, seperti pemanfaatan teknologi komputer pada proses pembelajaran di kelas dan diberikan kepada siswa untuk menerima secara visualisasi materi yang diberikan agar siswa tidak hanya menerima pengetahuan secara teoritik. Pembelajaran yang dimaksud adalah pembelajaran sibernetik.

Teori pembelajaran sibernetik berfokus pada pengelolaan informasi. Dalam teori sibernetik menurut Rachmad (2011), proses belajar memegang peranan penting, namun yang lebih penting lagi adalah pengolahan sistem informasi untuk memudahkan penyampaian materi pembelajaran yang akan disajikan kepada siswa. Menurut Suminar (2010, p.5) berpendapat bahwa hakekat manajemen pembelajaran berdasarkan teori belajar sibernetik adalah usaha guru untuk membantu siswa mencapai tujuan belajarnya secara efektif dengan cara memfungsikan unsur-unsur kognisi siswa, terutama unsur pikiran untuk memahami stimulus dari luar melalui proses pengolahan informasi.

Teori sibernetik mempunyai keunggulan dalam strategi pembelajaran yaitu: cara berfikir yang berorientasi pada proses lebih menonjol; penyajian pengetahuan memenuhi aspek ekonomis; kapabilitas belajar dapat disajikan lebih lengkap; adanya keterarahan seluruh kegiatan belajar kepada tujuan yang ingin dicapai; adanya transfer belajar pada lingkungan kehidupan yang sesungguhnya; kontrol belajar memungkinkan belajar sesuai dengan irama masing-masing individu; dan balikan informasi memberikan rambu-rambu yang jelas tentang tingkat unjuk kerja yang telah dicapai dibandingkan dengan unjuk kerja yang diharapkan (Thobrani \& Mustafa, 2012, p.188). 


\title{
Jurnal Riset Pendidikan Matematika, 4 (2), 2017 - 231
}

\author{
S. Salim, Era Maryanti
}

Keberhasilan pembelajaran matematika di sekolah juga tidak lepas dari peranan seorang guru dalam pengelolaannya. Setiap guru berkewajiban menyusun perangkat pembelajaran secara lengkap dan sistematis agar pembelajaran berlangsung secara interaktif, inspiratif, menyenangkan, menantang, memotivasi siswa untuk berpartisipasi aktif, kreativitas, dan kemandirian sesuai dengan bakat, minat, dan perkembangan fisik serta psikologis siswa. Azka \& Santoso (2015, p. 83) mengemukakan bahwa perangkat pembelajaran dapat digunakan sebagai pedoman guru dalam melaksanakan proses pembelajaran di kelas sehingga proses pembelajaran bisa berlangsung lebih terarah menuju kompetensi yang akan dituju. Perancangan dan penggunaan perangkat pembelajaran yang baik diduga kuat dapat lebih meningkatkan ketuntasan belajar dan kemandirian siswa.

Seorang guru sebelum mengajar diharapkan mempersiapkan perangkat pembelajaran yang memuat bahan yang mau diajarkan, media yang akan digunakan, dan persiapan pertanyaan dan arahan untuk memancing siswa aktif belajar, juga mempelajari keadaan siswa, mengerti kelemahan dan kelebihan siswa, serta mempelajari pengetahuan awal siswa. Namun, keadaan ini tidak sesuai dengan yang terjadi pada guru matematika kelas XI IPA SMA Negeri 1 Pasarwajo. Guru belum maksimal melakukan pengembang perangkat pembelajaran yang ada, penyusunan perangkat pembelajaran selalu mengikuti perangkat yang dibuat ditahun pelajaran sebelumnya, perangkat pembelajaran yang dibuat hanya sebagai dokumen administrasi untuk keperluan supervisi yang dilakukan oleh kepala sekolah maupun pengawas.

Kegiatan pembelajaran matematika dengan menggunakan teori pembelajaran sibernetik berbantuan software derive sangat memudahkan guru dalam memvisualisasikan konsep matematika yang diajarkan kepada siswa dengan tidak hanya memberikan materi secara teori, akan tetapi juga diberikan praktek komputasi yang memudahkan siswa dalam memahami materi yang diajarkan dan menyelesaikan masalah matematika yang bersifat konseptual, serta dapat membantu siswa dalam meningkatkan kemampuan berpikir kritisnya.

Teori pembelajaran sibernetik yang di dalam kemasannya terdapat penggunaan software derive diharapkan informasi yang diperoleh siswa diterima secara utuh dan tersimpan dalam sistem informasi. Penggunaan software derive disini agar pengetahuan teoritik melalui penyampaian materi akan diperkuat melalui visualisasi dengan bantuan software derive. Pengetahuan utuh yang diperoleh siswa dapat membangkitkan kemampuan berpikir kritis siswa dalam pembelajaran dan kehidupannya.

Fitur yang terdapat dalam software derive sehingga direkomendasikan untuk dijadikan software pembelajaran diantaranya: dapat membuat grafik 2D dan 3D; dapat membuat bangun geometri 2D dan 3D; dapat digunakan untuk menyelesaikan soal matematika, yang meliputi aljabar, kalkulus, trigonometri, matriks, dan lain-lain (Anonim, 2013a). Perlunya software dalam pembelajaran matematika juga diungkapkan oleh Fitriyani \& Sugiman (2014, p. 270) bahwa dampak kemajuan teknologi dalam pembelajaran matematika yaitu terciptanya software-software yang sangat membantu dan mempermudah penyelesaian masalah Matematika salah satunya Geogebra. Penggunaan software GeoGebra membantu siswa dalam meningkatkan pemahaman matematika melalui alternatif penyelesaian masalah yang mungkin dan membantu kesulitan belajar matematika siswa. Pemanfaatan software GeoGebra ini, diharapkan para siswa dapat membangun pengetahuannya tentang materi matematika.

Tujuan dalam penelitian ini diantaranya: (a) menemukan karakteristik perangkat pembelajaran melalui teori pembelajaran sibernetik berbantuan software derive untuk meningkatkan kemampuan berpikir kritis matematis siswa kelas XI IPA, (b) mendeskripsikan kevalidan perangkat pembelajaran melalui teori pembelajaran sibernetik berbantuan software derive untuk meningkatkan kemampuan berpikir kritis siswa kelas XI IPA, (c) mengkaji keefektifan pembelajaran dengan menggunakan perangkat pembelajaran melalui teori pembelajaran sibernetik berbantuan software derive untuk meningkatkan kemampuan berpikir kritis matematis siswa kelas XI IPA, (d) mengkaji peningkatan kemampuan berpikir kritis matematis dengan menggunakan perangkat pembelajaran melalui teori pembelajaran sibernetik berbantuan software derive pada siswa kelas XI IPA.

\section{METODE}

Jenis penelitian ini adalan penelitian pengembangan atau Reseach and Development dengan menggunakan model pengembangan Plomp (1997) yang memuat: (a) tahapan investigasi awal; (b) tahapan perancangan; (c) tahapan realisasi/ konstruksi; (d) tahapan tes, evaluasi, 
dan revisi; (e) tahapan implementasi. Perangkat yang akan dikembangkan dalam penelitian ini meliputi: silabus, rencana pelaksanaan pembelajaran (RPP), bahan ajar, lembar kerja siswa (LKS), dan tes kemampuan berpikir kritis.

Penelitian pengembangan ini dilaksanakan di SMA Negeri 1 Pasarwajo Kabupaten Buton. Subyek kelas uji coba dilakukan pada siswa kelas XI IPA semester genap tahun pelajaran 2016/2017 dengan kelompok kelas yang digunakan sebanyak 2 kelas yakni 1 kelas eksperimen untuk pembelajaran dengan menggunakan perangkat pembelajaran berbantuan software derive dan 1 kelas kontrol untuk pembelajaran konvensional.

Tahapan pengembangan perangkat pembelajaran dalam penelitian ini menggunakan model Plomp (1997) yang dapat diuraikan sebagai berikut:

\section{Tahap Preliminary Investigation (Investigasi Awal)}

Tahap preliminary investigation juga disebut analisis kebutuhan atau analisis masalah. Pada tahap ini dilakukan identifikasi dan analisis diantaranya: (a) analisis kurikulum; (b) analisis kondisi siswa; (c) analisis materi; (d) analisis tugas.

\section{Tahap Design (Perancangan)}

Kegiatan tahap ini bertujuan untuk mendesain pemecahan masalah yang dikemukakan pada tahan investigasi awal. Langkah-langkah yang ditempuh dalam perancangan perangkat pembelajaran sebagai berikut yaitu (a) penyusunan rencana pembelajaran dasar dari penyusunan rencana pembelajaran; (b) pemilihan format perangkat pembelajaran; (c) desain awal.

\section{Tahap Realization/Construction (Realisasi/ Konstruksi)}

Tahapan ini merupakan kelanjutan fase perancangan untuk memperole pemecahan masalah. Pada fase ini disusunlah perangkat pembelajaran yakni Silabus, RPP, Bahan Ajar, LKS, dan Tes Kemampuan Berpikir Kritis. Hasil konstruksi diteliti kembali, apakah perencanaan pembelajaran telah menggambarkan secara operasional pada sintaks teori pembelajaran sibernetik berbantuan software derive, apakah teori-teori pendukung lainnya telah diterapkan dengan baik pada silabus, RPP, bahan ajar, dan lembar kegiatan siswa sehingga dapat menfasilitasi siswa belajar dalam mengkonstruksi pengetahuan matematika.
Hasil dari kegiatan ini disebut draf 1 perangkat pembelajaran matematika melalui teori pembelajaran sibernetik berbantuan software derive untuk meningkatkan kemampuan berpikir kritis siswa kelas XI IPA. Dengan demikian, jika draft telah selesai maka siap untuk diuji valid tidaknya oleh para ahli dan praktisi pendidikan.

\section{Tahap Test, Evaluation, and Revision (Tes, Evaluasi dan Revisi)}

Pada tahap ini, suatu pemecahan yang dikembangkan harus diuji dan dievaluasi dalam praktiknya. Kegiatan pada tahap ini dilakukan dengan langkah-langkah yaitu validasi draf 1, analisis hasil validasi, revisi, uji coba, analisis uji coba. Fase ini telah dilakukan berarti sudah diperoleh perangkat pembelajaran yang valid.

\section{Tahap Implementation (Implementasi)}

Pada tahap ini, perangkat pembelajaran yang telah valid akan digunakan dalam kegiatan uji coba dilapangan dengan tujuan untuk mendapatkan pembelajaran yang efektif dengan menggunakan perangkat pembelajaran yang dikembangkan.

Teknik pengumpulan data yang digunakan dalam penelitian ini mencakup, (a) data tentang validitas perangkat pembelajaran diambil dengan menggunakan lembar validasi, (b) data tentang aktivitas belajar siswa diambil dengan cara observasi menggunakan lembar observasi, (c) data kemampuan berpikir kritis diambil menggunakan tes kemampuan berpikir kritis, (d) data respons siswa terhadap pembelajaran diambil dengan menggunakan angket.

Teknik analisis data yang digunakan dalam penelitian ini meliputi analisis deskripsi dan analisis inferensial. Analisis terhadap kevalidan perangkat pembelajaran yaitu rata-rata penilaian validator minimal telah berada dalam kategori valid sampai sangat valid. Kategorisasi kevalidan dapat dilihat pada Tabel 1 .

Tabel 1. Kategorisasi Kevalidan

\begin{tabular}{ccc}
\hline No. & Interval Rata-Rata & Kategori \\
\hline 1. & $1,0 \leq \mathrm{Va} \leq 1,75$ & Tidak Valid \\
2. & $1,75<\mathrm{Va} \leq 2,50$ & Kurang valid \\
3. & $2,50<\mathrm{Va} \leq 3,25$ & Valid \\
4. & $3,25<\mathrm{Va} \leq 4,00$ & Sangat Valid \\
\hline
\end{tabular}

Analisis terhadap keefektifan perangkat pembelajaran dapat diukur pada indikator yaitu data aktivitas belajar siswa, (2) kemampuan berpikir kritis siswa, dan (3) respon siswa. Aktivitas siswa dikatakan efektif, jika masing 


\title{
Jurnal Riset Pendidikan Matematika, 4 (2), 2017 - 233
}

\author{
S. Salim, Era Maryanti
}

butir pengamatan berada pada kategori minimal aktif sampai sangat aktif.

Tabel 2. Kategorisasi Aktivitas Belajar Siswa

\begin{tabular}{ccc}
\hline No. & Interval Rata-Rata & Kategori \\
\hline 1. & $1,0 \leq \mathrm{Va} \leq 1,75$ & Tidak Aktif \\
2. & $1,75<\mathrm{Va} \leq 2,50$ & Kurang Aktif \\
3. & $2,50<\mathrm{Va} \leq 3,25$ & Aktir \\
4. & $3,25<\mathrm{Va} \leq 4,00$ & Sangat Aktif \\
\hline
\end{tabular}

Kemampuan berpikir kritis siswa dilihat dari: (a) adanya ketuntasan belajar siswa terhadap kemampuan berpikir kritis. Siswa dikatakan mencapai tuntas belajar apabila skor yang diperoleh yaitu 65. Pembelajaran dikatakan tuntas apabila banyaknya siswa dalam kelas mencapai ketuntasan minimal 70\%. Rumus yang digunakan untuk menghitung ketuntasan secara klasikal/ kelompok adalah sebagai berikut (Sudjana, 2005, p.233):

$$
z=\frac{\frac{x}{n}-\pi_{0}}{\sqrt{\frac{\pi_{0}\left(1-\pi_{0}\right)}{n}}}
$$

Hasil rumus tersebut dibandingkan dengan nilai $z$ tabel dengan taraf nyata $\alpha=5 \%$. Kriteria pengambilan keputusan, tolak Ho jika $\mathrm{Z}_{\text {hitung }} \geq \mathrm{z}_{0,5-\alpha}$, dan terima Ho jika $\mathrm{z}_{\text {hitung }}<\mathrm{z}_{0,5-\alpha}$. Kriteria selanjutnya, (b) adanya perbedaaan kemampuan berpikir kritis matematis siswa. Analisis statistik yang digunakan adalah uji independent sample t test (pihak kanan) dengan rumus yang digunakan adalah sebagai berikut (Sudjana, 2005, p.239):

$$
t_{\text {hitung }}=\frac{\overline{X_{1}}-\overline{X_{2}}}{S_{g a b} \sqrt{\frac{1}{n_{1}}+\frac{1}{n_{2}}}}
$$

Pengolahan data pada rumus tersebut dibantu menggunakan program SPSS dengan kriteria tolak $\mathrm{H}_{0}$, jika nilai signifikansi lebih kecil dari $\alpha=0,05$, dan terima $\mathrm{H}_{0}$, jika nilai signifikansi lebih besar dari $\alpha=0,05$. Indikator keefektifan berikutnya adalah respon siswa dengan kriteria yakni respon siswa dianggap positif, jika persentase yang diperoleh lebih dari $75 \%$.

Analisis terhadap peningkatan kemampuan berpikir kritis dapat dihitung berdasarkan selisih antara rata-rata akhir kemampuan berpikir kritis siswa dengan rata-rata awal kemampuan berpikir kritis siswa yang disajikan dalam bentuk diagram batang. Untuk melihat signifikansinya digunakan uji statistik yanitu uji paired sample $t$ test dengan pengolahan data meng- gunakan program SPSS. Dasar pengambilan keputusan dapat juga dilakukan dengan membandingkan nilai signifikansi yang terdapat pada output SPSS, dengan $\alpha=0,05$. Dengan kriteria tolak Ho, jika nilai signifikansi lebih kecil dari $\alpha$ $=0,05$, dan terima Ho, jika nilai signifikansi lebih besar dari $\alpha=0,05$.

\section{HASIL DAN PEMBAHASAN}

Tahapan dalam penelitian ini yang mencakup: fase investigasi awal; fase perancangan; fase realisasi/konstruksi; fase tes, evaluasi, dan revisi; dan fase implementasi. Pada fase investigasi awal, dilakukan beberapa telaah dengan obyek yaitu: analisis kurikulum, analisis kondisi siswa, analisis materi, dan analisis tugas.

Hasil analisis dokumen kurikulum matematika kelas XI IPA menunjukkan bahwa perangkat yang digunakan oleh guru matematika kelas XI IPA sangatlah terbatas hanya mencakup silabus dan RPP. Silabus yang digunakan tidak dikembangkan dan disesuaikan dengan potensi dan keadaan sekolah. Analisis kondisi siswa menunjukkan rentang usia siswa berada pada rentang 16 - 18 tahun sehingga memungkinkan siswa untuk dilatih menyelesaiakan masalah yang bersifat abstrak dan dapat menggunakan pola sendiri dalam menyelesaiakan suatu masalah. Kemampuan awal yang dimiliki siswa membawa pengaruh untuk mempelajari suatu materi tertentu. Pada materi turunan fungsi merupakan materi baru dikenal siswa dapat membuat siswa mengalami kesulitan jika tidak memahami konsep-konsep turunan fungsi dengan baik. Kesulitan yang sering dialami siswa dalam memahami materi turunan fungsi yaitu ketika siswa diberikan soal memuat beberapa konsep materi baik itu konsep turunan fungsi maupun gabungan konsep turunan fungsi dengan konsep materi lainnya yang saling berkaitan satu sama lainnya. Oleh karena itu, kegiatan pembelajaran harus didesain sebaik mungkin untuk memudahkan siswa dalam memahami konsep-konsep turunan fungsi

Analisis materi menunjukkan materi pelajaran dalam penelitian adalah turunan fungsi. Materi turunan fungsi ini akan menjadi materi yang sulit dipahami dengan siswa jika tidak didesain dengan baik. Materi pelajaran ini didesain dengan melihat sistematika materi, pokok-pokok materi, keterhubungan antar materi, dan keterhubungan dengan materi lainnya.

Analisis tugas meliputi kemampuan siswa dalam memahami materi turunan diantaranya 
siswa dapat: menentukan turunan fungsi disatu titik tertentu dengan definisi turunan; menentukan titik suatu fungsi jika fungsi turunannya diketahui; menentukan turunan pada fungsi aljabar; menentukan turunan tingkat tinggi pada fungsi aljabar; menyelesaikan soal yang berhubungan dengan fungsi aljabar; menentukan turunan fungsi trigonometri; mencari solusi dari turunan tingkat tinggi pada fungsi trigonometri; menentukan turunan dua fungsi komposisi; menentukan turunan tiga fungsi komposisi; menyelesaikan soal yang berhubungan dengan turunan fungsi komposisi; menentukan persamaan garis singgung sebuah kurva pada titik tertentu; menentukan persamaan garis singgung sebuah kurva pada garis tertentu.

Pada fase perancangan, perangkat yang dirancang yaitu silabus, RPP, bahan ajar, LKS, dan tes hasil belajar. Silabus yang dirancang mencakup standar kompetensi, kompetensi dasar, indikator pembelajaran, aspek berpikir kritis, materi ajar, kegiatan pembelajaran, penilaian, alokasi waktu, dan sumber belajar. RPP yang dirancang mencakup satuan pendidikan, mata pelajaran, kelas/program, standar kompetensi, kompetensi dasar, indikator, alokasi waktu, tujuan pembelajaran, materi ajar, model pembelajaran, langkah-langkah pembelajaran (pendahuluan, kegiatan inti, penutup), alat dan sumber belajar, dan penilaian. Bahan ajar yang dirancang memuat peta konsep, tujuan pembelajaran, materi ajar, contoh soal, tugas mandiri dan latihan soal.

Pada penyajian materi ajar dan contoh soal dalam isinya disajikan tahapan-tahapan penyelesaian soal yang mengarah pada kemampuan berpikir kritis. LKS berisi ringkasan materi pelajaran, dan soal-soal yang harus dikerjakan sendiri oleh siswa secara berkelompok. Bentuk penyelesaian soal menggunakan pola-pola penyelesaian yang mengarah pada kemampuan berpikir kritis. Untuk memastikan bahwa soal yang dikerjakan benar digunakan bantuan software derive untuk mengecek hasil kebenaran pekerjaan siswa dalam menyelesaikan soal pada LKS secara manual. Tes hasil belajar tersusun didalamnya memuat aspek kemampuan berpikir kritis.

Pada fase realisasi/konstruksi, disusunlah perangkat pembelajaran yakni silabus, RPP, bahan ajar, LKS, dan tes hasil belajar yang disesuaikan dengan teori pembelajaran sibernetik berbantuan software derive dan aspek kemampuan berpikir kritis siswa.
Pada fase tes, evaluasi, dan revisi, dilakukan beberapa kegiatan yaitu: validasi terhadap perangkat pembelajaran yang dilakukan oleh validator, dan revisi berdasarkan masukan dari validator. Para validator memberikan masukan terlebih dahulu agar perangkat pembelajaran yang dibuat sebaik mungkin. Masukan dari validator kemudian dianalisis selanjutnya dilakukan revisi terhadap perangkat pembelajaran. Hasil analisis validasi perangkat pembelajaran menunjukkan skor rata-rata berada pada kategori sangat valid. Adapun nilai rata-rata hasil validasi perangkat pembelajaran dapat dilihat Tabel 3 .

Tabel 3. Rata-Rata Hasil Validasi Perangkat

\begin{tabular}{cccc}
\hline No. & Perangkat & Rerata & Kriteria \\
\hline 1. & Silabus & 3,63 & Sangat Valid \\
2. & RPP & 3,73 & Sangat Valid \\
3. & Bahan Ajar & 3,85 & Sangat Valid \\
4. & LKS & 3,77 & Sangat Valid \\
5. & THB & 3,74 & Sangat Valid \\
\hline
\end{tabular}

Pada fase implementasi, perangkat pembelajaran yang telah revisi siap untuk diimplementasikan pada situasi pembelajaran di dalam kelas. Implementasi perangkat pembelajaran ini dilakukan untuk mengetahui apakah perangkat pembelajaran efektif digunakan dalam pembelajaran dan dapt meningkatkan kemampuan berpikir kritis matematis siswa.

Hasil aktivitas belajar siswa menunjukkan aktivitas belajar siswa pada kelas dengan menggunakan perangkat pembelajaran melalui teori pembelajaran sibernetik berbantuan software derive tergolong aktif. Adapun nilai rata-rata aktivitas belajar siswa setiap pertemuan disajikan pada Tabel 4.

Tabel 4. Rata-Rata Aktivitas Belajar Siswa

\begin{tabular}{ccc}
\hline No. & Pertemuan & Rata-Rata \\
\hline 1. & I & 2,85 \\
2. & II & 3,21 \\
3. & III & 3,42 \\
4. & IV & 3,37 \\
5. & V & 3,44 \\
& Total & 3,25 \\
\hline
\end{tabular}

Ketercukupan kemampuan berpikir kritis siswa dilihat dari adanya ketuntasan belajar siswa dan adanya perbedaaan kemampuan berpikir kritis siswa antara kelas yang diajar dengan perangkat pembelajaran menggunakan teori pembelajaran sibernetik berbantuan software derive dibandingkan kelas dengan pembelajaran konvensional. Pengujian ketuntasan belajar siswa secara klasikal pada kelas yang diajar dengan perangkat pembelajaran menggunakan teori pembelajaran sibernetik berbantu- 
an software derive digunakan uji proporsi pihak kanan. Rekapitulasi hasil uji ketuntasan belajar disajikan pada Tabel 5.

Tabel 5. Rekapitulasi Hasil

Uji Ketuntasan Belajar

\begin{tabular}{cccc}
\hline Aspek Pengukuran & $\mathbf{Z}_{\text {hitung }}$ & $\mathbf{Z}_{\text {tabel }}$ & Kriteria \\
\hline $\begin{array}{c}\text { Kemampuan Berpikir } \\
\text { Kritis }\end{array}$ & 1,77 & 1,65 & $\begin{array}{c}\text { Tolak } \\
\text { Ho }\end{array}$ \\
\hline
\end{tabular}

Rekapitulasi hasil uji ketuntasan belajar menunjukkan bahwa Ho ditolak. Hal ini berarti bahwa ketuntasan belajar secara klasikal baik itu hasil belajar maupun kemampuan berpikir kritis yang mendapat nilai $\geq 65$ telah mencapai ketuntasan minimal $70 \%$. Selanjutnya, pengujian perbedaan kemampuan berpikir kritis siswa digunakan uji independent sample t test (pihak kanan). Rekapitulasi hasil analisis data kemampuan berpikir kritis matematis siswa disajikan pada Tabel 6.

Tabel 6. Rekapitulasi Kemampuan Berpikir Kritis Matematis Siswa

\begin{tabular}{cccc}
\hline Aspek Pengukuran & $\mathbf{t}_{\text {hitung }}$ & $\mathbf{t}_{\text {tabel }}$ & Kriteria \\
\hline $\begin{array}{c}\text { Kemampuan Berpikir } \\
\text { Kritis }\end{array}$ & 8,590 & 1,669 & $\begin{array}{c}\text { Tolak } \\
\text { Ho }\end{array}$ \\
\hline
\end{tabular}

Pada Tabel 6 menunjukkan bahwa Ho ditolak. Hal ini berarti kemampuan berpikir kritis siswa pada kelas yang diajar dengan perangkat pembelajaran menggunakan teori pembelajaran sibernetik berbantuan software derive lebih baik dari pada kemampuan berpikir kritis siswa pada kelas yang diajar dengan pembelajaran konvensional.

Hasil analisis rerata total angket respon siswa menunjukkan nilai sebesar $89,58 \%$ siswa memiliki respon positif terhadap pembelajaran dengan mengggunakan perangkat pembelajaran melalui teori pembelajaran sibernetik berbantuan software derive dan sisa sebesar 10,42\% siswa memiliki respon negatif.

Peningkatan kemampuan berpikir kritis siswa hanya tertuju pada kelas yang diajar dengan menggunakan perangkat pembelajaran yang dikembangkan melalui teori pembelajaran sibernetik berbantuan software derive. Adanya peningkatan kemampuan siswa dapat dilihat dari perbedaan rata-rata kemampuan berpikir kritis sebelum dan sesudah mendapatkan perlakuan pembelajaran dengan perangkat pembelajaran melalui teori pembelajaran sibernetik berbantuan software derive. Peningkatan kemampuan berpikir kritis matematis siswa hanya sebesar 24,97 .

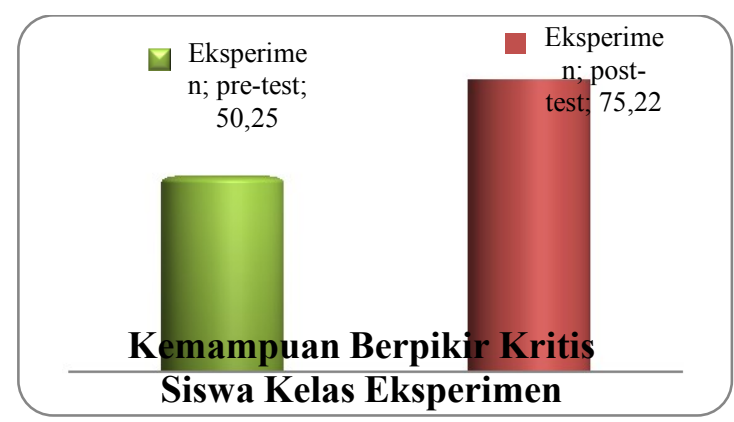

Gambar 1. Peningkatan Kemampuan Berpikir

Analisis statistik untuk mengetahui adanya peningkatan kemampuan berpikir kritis secara signifikan menggunakan uji paired sample $t$ test yang menunjukkan bahwa nilai thitung $=-10,171$ dengan nilai $\operatorname{sig}=0,000<$ 0,05 . Jadi, Ho ditolak artinya terdapat peningkatan yang cukup signifikan terhadap kemampuan berpikir kritis siswa dengan menggunakan perangkat pembelajaran melalui teori pembelajaran sibernetik berbantuan software derive.

Karakteristik perangkat pembelajaran dikembangkan diantaranya: karakteristik pertama, perangkat pembelajaran yang memuat aspek kemampuan berpikir kritis dilatarbelakangi dalam pembelajaran matematika yang perlu diberikan kepada semua peserta didik yaitu untuk membekali peserta didik dengan kemampuan berpikir logis, analitis, sistematis, kritis, dan kreatif. Siswa SMA sudah semestinya dilatih kemampuan berpikirnya dalam menyelesaikan masalah kehidupan sehari yang berhubungan dengan matematik dan menemukan pola tersendriri dari penyelesaian masalah tersebut. Karakteristik kedua, pengembangan perangkat pembelajaran yang menggunakan teknologi informasi dan komunikasi bertujuan untuk meningkatkan keefektifan pembelajaran sekolah. Pembelajaran saat ini perlu menggunakan teknologi dalam pembelajaran bertujuan untuk mempermudah kegiatan pembelajaran maupun sebagai sumber dan bahan belajar. Trend penggunaan teknologi dalam pembelajaran memunculkan inovasi baru dalam pembelajaran dan semangat baru baik bagi guru maupun siswa.

Visualisasi dari penggunaan teknologi akan membantu siswa untuk memahami konsep matematika yang abstrak. Salah satu penggunaan teknologi dalam pembelajaran yaitu teknologi komputer dengan penunjang aplikasi matematika yang digunakan yaitu software derive. Mengenai materi pelajaran yang dijarkan adalah materi turunan merupakan materi yang sangat menarik untuk dieksplorasi menggunakan software derive. Menarik karena konsep-konsep 


\title{
Jurnal Riset Pendidikan Matematika, 4 (2), 2017 - 236
}

\author{
S. Salim, Era Maryanti
}

dasar turunan mudah ditemukan/dieksplorasi dan mudah untuk divisualisasikan suatu persamaannya dalam bentuk grafik atau keperluan lainnya.

Teori pembelajaran sibernetik yang didalam kemasannya terdapat penggunaan software derive agar informasi yang diperoleh siswa diterima secara utuh dan tersimpan dalam sistem informasi. Dalam hal ini, pengetahuan teoritik melalui penyampaian materi akan diperkuat melalui manipulasi matematik dengan bantuan software derive. Pengetahuan utuh yang diperoleh siswa dapat membangkitkan kemampuan berpikir kritis siswa dalam pembelajaran dan kehidupannya.

Penggunaan software derive bertujuan untuk memperkuat pengetahuan teoritik melalui penyampaian materi langsung oleh guru melalui visualisasi yang terdapat pada software derive. Hasil penelitian ini sejalan dengan penelitian Andresen (2007) yang dilakukan pada Sekolah Menengah Atas di Denmark yang menggunakan pendekatan pemodelan pada materi persamaan diferensial yang menggunakan komputer berbantuan software derive menunjukkan software derive digunakan untuk memfasilitasi proses perubahan yang berfokus pada pemecahan persamaan secara kualitatif, interpretasi grafik yang berbeda setiap kasus.

Hasil pengamatan terhadap aktivitas belajar siswa juga mendukung teori belajar yang dikemukakan oleh Piaget dan Vygotsky dalam Trianto (2009) bahwa pengetahuan dibangun secara aktif oleh peserta didik melalui interaksi dan kerja sama dengan peserta didik lainnya sebagai perwujudan interaksi dengan lingkungannya. Aktivitas siswa selama proses pembelajaran ini sangat menunjang siswa untuk menguasai materi yang diberikan guru sehingga hasil belajar matematika siswa semakin meningkat. Dengan demikian analisis terhadap pengamatan aktivitas belajar siswa menunjukkan aktivitas belajar siswa efektif.

Perbedaan hasil belajar juga tidak hanya dipengaruhi oleh faktor internal. Pelaksanaan pembelajaran yang menggunakan suatu perangkat pembelajaran yang benar akan berkualitas dan perannya dapat membantu guru melaksanakan pembelajaran dan membantu siswa mengikuti pembelajaran dan menguasai materi yang diberikan guru. Dengan demikian, faktor internal seperti psikologis siswa dan faktor eksternal seperti perangkat pembelajaran dan profesionalitas guru dalam mengajar perlu senantiasa diupayakan guru untuk diwujudkan atau diperhatikan selama proses pembelajaran. Penggunaan perangkat pembelajaran yang berbeda akan menghasilkan perbedaan pada pencapaian belajar siswa. Jika dilihat dari karakteristik masing-masing pembelajaran yang digunakan dalam penelitian ini, tampak bahwa perbedaan kemampuan siswa tersebut memang tampak terjadi.

Hasil analisis data rata-rata kemampuan berpikir kritis menunjukkan ada perbedaan antara kedua kelompok perlakuan setelah siswa mengikuti pembelajaran. Kelompok siswa yang mendapat pembelajaran dengan menggunakan perangkat pembelajaran melalui teori pembelajaran sibernetik berbantuan software derive lebih baik dari pada kelompok siswa yang mendapat pembelajaran konvensional. Pada pengujian statistik independent sample $t$ test (pihak kanan) yang menunjukkan bahwa kemampan berpikir kritis pada kelompok siswa yang mendapat pembelajaran dengan perangkat pembelajaran melalui teori pembelajaran sibernetik berbantuan software derive lebih baik dari pada hasil belajar kelompok siswa yang mendapat pembelajaran konvensional.

Hasil penelitian ini juga relevan dengan beberapa hasil penelitian lainnya. Pertama, penelitian yang dilakukan Chukwuyenum (2013), hasilnya menunjukkan keterampilan berpikir kritis merupakan sarana yang efektif untuk meningkatkan pemahaman siswa terhadap konsep matematika. Oleh karena itu dalam pembelajaran matematika di sekolah menengah, keterampilan berpikir kritis harus ditanamkan dalam kurikulum pendidikan guru sehingga dapat meningkatkan kinerja siswa dalam belajar matematika. Kedua, penelitian yang dilakukan Lunenburg (2011), hasilnya menunjukkan terdapat dua pendekatan untuk mengajar materi pelajaran yaitu berpikir kritis dan konstruktivisme yang dapat mengakibatkan peningkatan yang besar terhadap prestasi siswa sehingga siap untuk menjadi warga negara yang bertanggung jawab, belajar ditingkat lebih tinggi, dan mendapat lapangan kerja yang produktif untuk kepentingan ekonomi bangsa. Ketiga, penelitian yang dilakukan oleh Ayda \& Widjajanti (2014), hasilnya menunjukkan bahwa perangkat pembelajaran hasil pengembangan yang berupa silabus, RPP, LKS, dan media pembelajaran berbantuan komputer dalam penelitiannya telah efektif ditinjau dari prestasi belajar siswa, yaitu $76,67 \%$ siswa memperoleh nilai tes akhir melampaui KKM dan sebanyak 83,34\% memi- 
liki skor mathematics self efficacy minimal pada kategori tinggi.

Perangkat pembelajaran melalui teori pembelajaran sibernetik berbantuan software derive mendapat respon yang positif dari siswa karena dalam pelaksanaannya, perangkat ini mampu mengaktifkan siswa dalam belajar. Dari berbagai pernyataan yang digunakan dalam mengkaji respon siswa tampak bahwa mayoritas jawaban siswa diantaranya: senang dengan komponen dan perangkat pembelajaran, merupakan komponen dan perangkat baru dalam pembelajaran, berminat mengikuti pembelajaran selanjutnya, memahami dengan jelas bahasa yang digunakan dalam perangkat, mengerti terhadap soal/masalah yang disajikan dalam perangkat pembelajaran, tertarik pada penampilan perangkat pembelajaran, dan mudah memahami isi dalam perangkat pembelajaran yang digunakan. Hasil penelitian ini juga relevan dengan hasil penelitian yang dilakukan oleh Firmasari, Sukestiyarno, dan Mariani (2013) yang menunjukkan bahwa respon siswa terhadap komponen dan kegiatan pembelajaran positif terhadap pengembangan bahan ajar menggunakan taksonomi solo superitem dengan tutor sebaya berbantuan software wingeom.

Pembelajaran yang efektif tentunya tidak terlepas dari peranan seorang guru dalam mendesain suatu pembelajaran. Gurulah yang mengetahui semua potensi yang ada pada lingkungan sekolah, strategi pembelajaran yang digunakan, kompetensi/kemampuan yang harus dikuasai oleh siswa. Perlunya guru yang kompeten juga diteliti oleh Thompson (2008) tentang pengetahuan guru terhadap higher-order thinking. Hasilnya menunjukkan bahwa sebesar $55 \%$ guru matematika sekolah menengah atas di bagian tenggara Amerika Serikat memiliki pengetahuan higher-order thinking terhadap taksonomi Bloom dan sebesar 100\% guru matematika di sekolah menengah atas tenggara Amerika Serikat memiliki pengetahuan tentang low-order thinking terhadap taksonomi Bloom. Penelitian Thompson ini lebih mengarah pada kemampuan berpikir tingkat tinggi yang harus dikuasai oleh guru. Sementara pada penelitian ini yang melatarbelakangi perlunya dilatih kemampuan berpikir kritis siswa diakibatkan guru belum pernah melatih kemampuan berpikir kritis siswa. Penguasaan terhadap aspek-aspek kemampuan berpikir kritis dan berpikir lainnya mesti dikuasai dan dipahami oleh guru. Penguasaan ini bertujuan agar memudahkan siswa untuk menyelesaikan suatu masalah/soal. Jadi faktor guru juga berperan terhadap keberhasilan belajar siswa

\section{SIMPULAN DAN SARAN}

\section{Simpulan}

Simpulan dari penelitian ini diantaranya: (1) Karakteristik perangkat pembelajaran yang dikembangkan memuat: aspek-aspek kemampuan berpikir kritis, dan penggunaan teknologi informasi dan komunikasi; (2) Perangkat pembelajaran melalui teori pembelajaran sibernetik berbantuan software derive untuk meningkatkan kemampuan berpikir kritis matematis siswa kelas XI IPA telah valid setelah dinilai oleh para validator dengan sedikit saran revisi; (3) Keefektifan pembelajaran telah memenuhi indikator diantaranya: aktivitas belajar siswa menjadi aktif, ketuntasan belajar telah tercapai, tedapat perbedaan kemampuan berpikir kritis siswa antara dua kelompok perlakuan pembelajaran, dan siswa memberikan respon positif; (4) Terdapat peningkatan rata-rata kemampuan berpikir kritis siswa yang cukup signifikan sebesar 24,96 setelah mendapatkan pembelajaran dengan menggunakan perangkat pembelajaran melalui teori pembelajaran sibernetik berbantuan software derive untuk meningkatkan kemampuan berpikir kritis matematis siswa kelas XI IPA.

\section{Saran}

Saran yang dapat dikemukakan diantaranya: (1) guru matematika kelas XI IPA dapat menggunakan perangkat pembelajaran ini untuk melengkapi perangkat pembelajaran yang ada, dan dapat dijadikan sarana atau sumber belajar di sekolah, (2) perangkat pembelajaran yang dikembangkan melalui teori pembelajaran sibernetik berbantuan software derive tidak hanya pada materi turunan saja tetapi dapat digunakan untuk materi-materi lain yang mudah dieksplorasi dengan software derive, (3) perlunya penggunaan teknologi dalam pembelajaran untuk memotivasi dan menarik perhatian siswa dalam belajar dan memudahkan guru untuk mengorganisasikan pembelajaran.

\section{DAFTAR PUSTAKA}

Andresen, M. (2007). Modeling with the software 'derive' to support a constructivist approach to teaching. International Electronic Journal of Mathematics Education, Volume 2, No 1, Hal: 1-15. 


\section{Jurnal Riset Pendidikan Matematika, 4 (2), 2017 - 238}

S. Salim, Era Maryanti

Anonim. (2013a). Derive 6 GCSE \& A Level Maths Brought to Life. Retrieved from http://www.chartwellyorke.com/derive.ht $\mathrm{ml}$

Anonim. (2013b). Other Definitions of Critical Thinking Retrieved from http://www.criticalthinking.com/articles/c ritical-thinking-definition\#

Ayda, E., \& Widjajanti, D. (2014). Pengembangan perangkat pembelajaran teorema pythagoras dengan media berbantuan komputer. Jurnal Riset Pendidikan Matematika, 1(2), 216-226. doi:http://dx.doi.org/10.21831/jrpm.v1i2. 2677

Azka, R., \& Santoso, R. (2015). Pengembangan perangkat pembelajaran kalkulus untuk mencapai ketuntasan dan kemandirian belajar siswa. Jurnal Riset Pendidikan Matematika, 2(1), $78 \quad$ - 91. doi:http://dx.doi.org/10.21831/jrpm.v2i1. 7152

Chukwuyenum, A. N. (2013). Impact of critical thinking on performance in mathematics among senior secondary school students in Lagos State. IOSR Journal of Research \& Method in Education (IOSR-JRME). Volume 3, Issue 5, Halaman 18-25.

Jacobsen, D.A., Eggen, P., \& Kauchak, D. (2009). Method for teaching. Yogyakarta: Pustaka Pelajar.

Firmasari, S., Sukestiyarno, YL., \& Mariani, S. (2013). Pengembangan bahan ajar menggunakan taksonomi solo superitem dengan tutor sebaya berbantuan software wingeom. Unnes Journal of Mathematics Education Research, Volume 2, No. 1, Hal: 184-189.

Fitriyani, W., \& Sugiman, S. (2014). Pengembangan perangkat pembelajaran teorema pythagoras dengan pendekatan ideal berbantuan geogebra. Jurnal Riset Pendidikan Matematika, 1(2), 269-284. doi:http://dx.doi.org/10.21831/jrpm.v1i2. 2681
IEA (International Association for the Evaluation of Educational Achievement). (2011). Towards Equity and Excellence Highlights from TIMSS 2011 The South African perspective.

Lunenburg, F. C. (2011). Critical thinking and constructivism techniques for improving student achievement. National Forum Of Teacher Education Journal, Volume 21, No.3, Hal: 1-9.

Murwani, E. D. (2006). Peran guru dalam membangun kesadaran kritis siswa. Jurnal Pendidikan Penabur, Nomor 06/Th.V, Hal: 59-68.

Plomp, T. (1997). Educational design: introduction, from Tjeerd Plomp (Eds.) Educational \& Training System Design: Introduction. Design of Educational and Training (in Dutch). Utrecht (the Netherlands): Lemma, Netherland. Faculty of Educational Science and Technology, University of Twente.

Rachmad, E. (2011). Aplikasi teori belajar sibernetik. Retrieved from http://waspadamedan.com/index.php?opti on $=$ com_content\&view $=$ article $\& i d=9613$ : aplikasi-teori-belajar-sibernetik$\&$ catid $=59$ :opini\&Itemid $=215$, diakses 28 Maret 2016

Sudjana. (2005). Metode statistika. Bandung: Tarsito

Suminar, T. (2010). Tinjauan filsafati (Ontologi, epistemologi, dan aksiologi) manajemen pembelajaran berbasis sibernetik. Jurnal Edukasi, Nomor 3 tahun 2010, Hal: 1-16.

Thobrani, M., \& Mustafa, A. (2012). Belajar \& Pembelajaran. Jogjakarta: Ar- Ruzz Media.

Thompson, T. (2008). Mathematics teachers' interpretation of higher-order thinking in Bloom's taxonomy. International Electronic Journal of Mathematics Education, Volume 3, No 2, Hal: 96-109.

Trianto. (2009). Mendesain model pembelajaran inovatif kontemporer. Jakarta: Bumi Aksara. 